HOW

Volume 29, Number 1, pages 212 - 231

https://doi.org/10.19183/how.29.1.631

HOW

\title{
An Overview of Dominant Approaches for Teacher Learning in Second Language Teaching
}

\author{
Una Mirada General de los Enfoques Dominantes para el \\ Aprendizaje Docente en la Enseñanza de Segundas Lenguas
}

\author{
Diego Fernando Macías ${ }^{1}$ \\ Universidad Surcolombiana, Neiva, Colombia \\ Wilson Hernández-Varona ${ }^{2}$ \\ Concordia University, Montreal, Canada
}

\begin{abstract}
The current review offers an analysis of the prevailing literature on teacher learning in language teaching from an international perspective. We initially revisit several contributions from a general education perspective. Then, we focus on three dominant approaches, identified through the literature, to understand teacher learning from a language teaching perspective. Finally, we provide implications for teacher educators to consider in the preparation of prospective language teachers. These include acknowledging future teachers' prior cognitions and learning experiences, highlighting the benefits of collaborative work and communities of practice, and adapting and innovating within the social constraints of their teaching context.

Keywords: language teacher education, learning to teach, second language teaching, teacher cognition, teacher learning

$212 \quad$ ORCID ID: https://orcid.org/0000-0003-4750-6714

He is an associate professor of English in the College of Education at Universidad Surcolombiana in Neiva, Colombia. His research and professional interests span the areas of language teacher education and professional development, classroom management, and teaching English as an International Language.

2 He is a Ph.D. student in the department of Education, at Concordia University in Montreal, Quebec. His current research interests are constituting teacher subjectivities in conflict and post-conflict environments, oral history research, and teacher education and development.

wilson.hernandez@mail.concordia.ca

ORCID ID: https://orcid.org/0000-0003-0383-0088
\end{abstract}

Received: January 19th, 2021. Accepted: October 26th, 2021.

This article is licensed under a Creative Commons Attribution-Non-Commercial-No-Derivatives 4.0 International License. License Deed can be consulted at https://creativecommons.org/licenses/by-nc-nd/4.0. 
An Overview of Dominant Approaches for Teacher Learning in Second Language Teaching

\section{Resumen}

La presente revisión ofrece un análisis de la literatura predominante sobre el aprendizaje docente en la enseñanza de lenguas desde una perspectiva internacional. Inicialmente, revisamos varias contribuciones desde una perspectiva de la educación en general. Luego, nos centramos en tres enfoques dominantes, identificados a través de la literatura, para entender el aprendizaje docente desde la perspectiva de la formación de los profesores de lenguas. Finalmente, ofrecemos algunas implicaciones para ser tenidas en cuenta por formadores de docentes en la preparación de futuros profesores de lenguas. Estas incluyen el reconocimiento de las experiencias previas de aprendizaje de los futuros docentes, el beneficio del trabajo colaborativo y las comunidades de práctica, y la adaptación e innovación dentro de las limitaciones sociales de su contexto de enseñanza.

Palabras clave: aprender a enseñar, aprendizaje docente, conocimiento docente, enseñanza de segundas lenguas, formación de docentes de lenguas

\section{Introduction}

Research on teacher learning from a general education perspective is rather extensive. We - the authors - revisit here a number of key constructs in an attempt to make possible connections with the field of second language ${ }^{3}$ teacher education. One initial consideration relates to the role played by teachers as learners, as they move through the different stages of general and specialized education. Lortie (1975) captures this in the concept of "apprenticeship of observation" as "the phenomenon whereby student teachers arrive for their training courses [after] having spent thousands of hours as schoolchildren observing and evaluating professionals in action" (Borg, 2004, p. 274). It follows that teachers' personal past experiences as students are likely to influence how teachers learn to teach. Teachers are largely "self-made" and they "emerge from their induction experiences with a strongly biographical orientation to pedagogical decision-making” (Lortie, 1975, p. 81).

Kolb's (1984) experiential learning cycle is equally relevant. It consists of four modes: concrete experience involves intuitive or 'gut' feeling; reflective observation, that is, perception and comprehension of what happened; abstract conceptualization, which requires the teacher to think and formulate a concept in relation to what happened whereas active experimentation involves the teacher trying and applying what he learned from a teaching event in a subsequent lesson. Eventually, this active experimentation will require further concrete experience and so the cycle goes on. Joyce and Showers (2002, as cited in Hammerness, Darling-Hammond, \&

\footnotetext{
We thought of 'second language' as the field often seems to be referred to as 'second language teacher education' across many international settings and sources. Our choice of 'second language' is also related to Graddol (2006), who claims that the term English as a 'foreign Language' "tends to highlight the importance of learning about the culture and society of native speakers; it stresses the centrality of methodology in discussions of effective learning; and emphasizes the importance of emulating native speaker language behaviour" (p. 82). The previous argument goes against the perspective from which this review has been constructed.
} 
Bransford, 2005) similarly state that teachers go through an iterative process of learning, experimenting, and reflecting as they develop new skills for use in their classrooms.

Hammerness et al. (2005) describe the concept of teachers' adaptive expertise as something that supports lifelong learning and may involve giving up old routines and transforming prior beliefs and practices. This adaptive expertise appears to be a response to the fact that knowledge, skills, and attitudes for effective teaching cannot be fully developed in pre-service teacher education programs. Hammerness et al. (2005) conclude that teachers learn to teach within a community that enables them to develop the following aspects: A vision for what they want to do in their practice; a set of understandings about teaching, learning, and children; dispositions or habits of thinking about how to use that knowledge; practices that facilitate the implementation of various instructional activities for student learning; and tools that support their efforts. These tools can be of a conceptual nature (e.g., learning theories, frameworks, ideas about teaching and learning) or a practical nature (e.g., instructional approaches and strategies, resources, textbooks, etc.).

Feiman-Nemser (2008) conceptualizes learning to teach in terms of four broad themes: learning to think like a teacher, learning to know like a teacher, learning to feel like a teacher and learning to act like a teacher. Learning to think like a teacher involves "a critical examination of one's existing beliefs, a transition to pedagogical thinking, and the development of metacognitive awareness" (p. 698). Learning to know like a teacher emphasizes the various kinds of knowledge that are inherent to good teaching. Feiman-Nemser (2008) adds that teachers need deep knowledge of subject matter and how to teach it, knowledge of how children grow and learn, of the influence of culture and language on learning, knowledge about "curriculum, pedagogy, classroom organization and assessment...and the broad purposes of schooling and how those purposes affect their work" (p. 699).

Learning to feel like a teacher refers to the emotional, personal, identity-related side of teaching while learning to act like a teacher involves a kind of instinct or personal judgement to know what to do when and next, that is, to figure out how to act or react to the multitude of circumstances that characterize teaching. Feiman-Nemser (2008) finally considers that teachers have to learn to combine the various ways of thinking, knowing, feeling, and acting into a principled and responsive teaching practice. This can be achieved inside the classroom by 214 means of engaging in "a wide range of activities — explaining, listening, questioning, managing, demonstrating, assessing, inspiring" and outside the classroom where teachers can "plan for teaching, collaborate with colleagues, and work with parents and administrators" (p. 699).

In short, the literature in general education shows that learning to teach is an a priori process and goes way beyond the boundaries of formal teacher preparation. It is certainly not a passive process of merely receiving new information. Feiman-Nemser (2008) points out that just like all learners, 
An Overview of Dominant Approaches for Teacher Learning in Second Language Teaching

Teachers interpret new knowledge and experience through their existing beliefs and modify and reinterpret new ideas on the basis of what they already know and believe. What teachers learn is also influenced by the social and cultural contexts where knowledge is acquired and used, including the particulars of subject matter and students. (p. 700)

The above description captures what seems to be a common view of learning to teach from a general education perspective. In this regard, Barnes and Smagorinsky (2016) conclude that teacher education programs constitute only one (not necessarily the primary) source of learning for beginning teachers. They claim that there are factors such as the apprenticeship of observation, the politics of the school environment, the community, their individual and personal lives, among others, that are often overlooked or taken for granted, but that can be equally accountable for teachers' conceptions of effective teaching. These authors also stress that teacher candidates make sense of those influential factors in different ways.

Several authors (for instance, Freeman, 1989, 1996b; Tarone \& Allwright, 2005; Johnson, 2009b, Wright, 2010) have claimed that despite an interest in what second language teachers need to know and the influence of areas such as applied linguistics, second language acquisition, and teaching methodologies, how teachers learn to teach is an area in need of further research and discussion. As Freeman and Johnson (1998) note, the task of understanding the complex nature of how teachers learn to teach should be an area of common interest for pre-service teachers, in-service teachers, policy makers, teacher educators, and the community at large. Currently, teacher learning in second language teacher education is becoming a relevant field of study as it takes more complex and exciting directions.

It is our goal in this paper to review the literature on how second language teachers learn to teach across international contexts ${ }^{4}$. We similarly aim to consolidate teacher learning as a relevant issue in the preparation of language teachers and to raise awareness among practicing teacher educators in second language teacher education to better respond to the many challenges derived from the activity of learning to teach. We will start with an overview of the most dominant approaches for teacher learning in the field of international second language teacher education followed by a more detailed perspective of current trends in learning to teach in the same field. Then, we will provide conclusions and implications for language teacher educators in diverse international contexts.

It is not our goal to limit this review to a particular context. This manuscript gathers what we read and observed across a number of conceptual and empirical sources that (explicitly or implicitly) address the phenomenon of teacher learning in language teacher education from a general perspective for the most part. Interestingly, many of those sources appear to be implicitly referring to the field of language teacher education as a worldwide phenomenon. Put differently, we aim to provide an overview of what has been happening to teacher learning in language teaching as observed in the sources consulted and cited. 


\section{Dominant Approaches to Teacher Learning in Second Language Teacher Education}

In examining the literature, we identified three dominant approaches on the subject of teacher learning in second language teacher education from an international perspective. These approaches serve to inform how teachers conceptualize teaching and how various scholars believe teachers learn to teach. We must clarify that there may be inevitable overlapping between these approaches as learning to teach involves a multiplicity of factors and practices which make it a long and complex process that starts even before prospective teachers enroll in teacher preparation programs and continues into their years of professional teaching.

\section{Content Knowledge + Teaching Skills = Effective Teaching}

This first approach follows a behavioral orientation, supports the notion of teaching as transmission, and is based on the process-product paradigm in general education which emphasizes the connection between a teacher's actions and students' learning outcomes. Teaching effectiveness within a process-product paradigm is determined "in terms of relationships between measures of teacher classroom behavior (processes) and measures of student learning outcomes (products)" (Doyle, 1977, p. 165). This paradigm clearly implies a causal relationship between what teachers do and what students are able to achieve at the end of an instructional sequence. One of the challenges here is that this relationship may lead to disregarding other variables, different from teacher variables, which may equally affect student learning outcomes. This first approach also relies on the belief that content knowledge and teaching skills would be sufficient for teachers to convey the content to students, that is, second language teachers were supposed to have knowledge of the target language and knowledge of a series of methods and techniques to be able to teach. As Freeman (2016) further argues, the teacher needed to "know the what as it was defined through the disciplines" ... [and] "to know the how of various methodologies and more crucially have a basis on which to choose among these different 'bow's' (p. 166).

According to Freeman (2002), new teachers were considered to enter professional training tabula rasa, "with no prior knowledge of teaching or the teachers' role" (p. 5). Teachers were then seen as doers and implementers of other people's ideas and thoughts in the classroom without much consideration for the physical and social contexts where learning would occur. This also seems to correspond to the craft and applied science models proposed by Wallace (1991) through which beginning teachers learn from observing and imitating the behavior and techniques of more experienced teachers, and applying the theoretical and scientific concepts given by experts. These models promote the transmission of knowledge in a top-down fashion and seek to maintain a separation between the expert or researcher and the teacher. Another concept that may be associated with this first approach 
is the 'learn-then-apply' design. Accordingly, teacher candidates "are expected to develop subject-matter knowledge in their first years of university study, and to then refine it as they apply it in practice teaching and school settings in later years" (Freeman, 2016, p. 189).

This first approach seemingly relates to a micro approach to teacher education (Richards, 1987, 1990), which considers teaching in terms of its most visible characteristics. Teachers were prescriptively taught discrete teaching skills (e.g., giving instructions, monitoring students' work, etc.) and their effectiveness relied on mastering a repertoire of those skills and knowledge. Further evidence can be found in Freeman's (1996a) behavioral view of teaching which describes teaching as doing, in terms of teachers' and learners' behaviors in the classroom. In short, emphasis was on training teachers to imitate a series of teaching/teacher behaviors and methodologies that had proved to be successful in other countries.

Teacher education programs worldwide expose future teachers to a great amount of disciplinary knowledge, typically in the form of methods and theories; and provide them with a field experience (teaching practicum) in which they are expected to apply their theoretical knowledge regardless of the context of actual classrooms. Not surprisingly, Atay (2004) contends that current education and training programs "are found to be insufficient due to the fact that they do not provide the participant teachers with opportunities to reflect on their own experiences, nor do they give them support in modifying teaching practice" (p. 143). This perspective of teacher learning has similarly led to reinforce the view of language teacher education as front loading and updating (Freeman, 2016), that is, most of the knowledge and skills teachers need in order to teach can be front loaded or given at the beginning of their teaching career. It then follows that teachers are expected to continue their professional learning particularly by means of professional development activities, also known as 'updating' opportunities which tend to "reinforce the assumption that the core knowledge comes in initial preparation at the start of teaching" (p. 192). This act of front loading in teacher education tends to overlook the contributions of the actual experiences associated with doing the job in the classroom.

Freeman (1989) seemingly criticized the misconception that a transmission of knowledge about applied linguistics and language acquisition, usually based on theoretical readings, university-based lectures, and/or professional development workshops, was enough for an effective pre-service language teacher. It is based on the misconception that Freeman and Johnson (1998) later states as:

Teacher educators have come to recognize that teachers are not empty vessels waiting to be filled with theoretical and pedagogical skills. They are individuals who enter teacher education programs with prior experiences, personal values, and beliefs that inform their knowledge about teaching and shape what they do. (p. 401) 
It is precisely this final statement that leads us to the second dominant approach for teacher learning in language teacher education that highlights the mental side, prior beliefs, and learning experiences of language teacher learners.

\section{Teachers' Hidden Pedagogy and Prior Experiences}

The second approach to teacher learning in global settings seeks to move from teachers' behaviors and actions to examining their thinking and past experiences. A common assumption here is that what teachers do in the language classroom originates in thoughts or mental acts and that is equally shaped by teachers' experiences; a number of them can play a more noticeable role than others. Duarte (1998) states that "to understand how teachers learn to teach and how they come to conceptualize what they do, we need to focus on the mental lives of teachers" (p. 618). It follows that concepts such as teachers' beliefs, decision making, hidden pedagogy, reflection, apprenticeship of observation, and personal theories of learning play a more prominent role as teachers in diverse contexts are encouraged to turn to their cognitions and reflect on how their past learning experiences interact with their present ways of thinking.

Borg (2006) defines teacher cognition as the "complex, practically-oriented, personalized, and context-sensitive networks of knowledge, thoughts and beliefs that language teachers draw on in their work" (p. 272). Accordingly, four areas contribute to shape teacher cognition: "schooling... which defines early cognitions" to "professional coursework... [which] may affect existing cognitions", to "contextual factors ... [which] influence practice" (p. 272). The previous three areas lead to "classroom practice" which is "defined by the interaction of cognitions and contextual factors" (Borg, 2003, p. 82). Borg (2009) later claims that "we cannot make adequate sense of teachers' experiences of learning to teach without examining the unobservable mental dimension of this learning process" (p. 163). This represents language teachers' inner voices, which are built over time and tested against different circumstances and teaching settings. Reflection therefore plays a crucial role in helping teachers to explore or make better use of their implicit theories of teaching. Thus, Richards (1998) claims that "reflective approaches often seek to engage teachers in articulating and examining the assumptions that underlie their teaching and in developing personal principles of best

218 practice that can support their approach to teaching" (p. 3).

Wallace's (1991) reflective model that encourages teachers to constantly reflect upon, evaluate, and modify their own teaching practice also belongs to this second approach of learning to teach second languages. This reflective model, according to Wallace (1991), includes 'received knowledge' and 'experiential knowledge'. The former refers to the theories, skills, and research findings that usually constitute the intellectual content of the profession whereas experiential knowledge makes reference to the knowledge gained by the practice of 
the profession and the chance to constantly reflect on knowledge-in-action ${ }^{5}$. Wallace (1991) also adds that the reflective model highlights what teacher learners bring to the training process and therefore recognizes that they do not come with empty minds hoping to merely receive knowledge from others. Despite the relevance of the reflective model, Buendia \& Macías (2019) suggest that language teacher professional development in Colombia is moving "from applied science (Schon, 1987) and reflective-cooperative-process models (Wallace, 1991) towards more critical ones in which basic aspects such as the design criteria for professional development programs, teachers' roles, and teachers' ways of learning, have been redefined" (p. 108).

This approach reflects a macro approach to teacher education (Richards, 1987, 1990) and follows a non-prescriptive orientation through which teachers are offered opportunities to "focus on clarifying and elucidating the concepts and thinking processes that guide effective language teaching" (Richards, 1990, p. 14). Similarly, Freeman's (1996a) cognitive view recognizes teachers as affective and thinking beings. Thus, not only do teachers know the behaviors but they also articulate this knowledge in order to cope with unexpected and complex situations that arise in the actual teaching practice. There is a growing interest not only in what teachers do in the classroom but in what they think about as they do it (Freeman, 1996a). An equally relevant theme here relates to language teachers' decisionmaking. Woods' (1996) ethno-cognitive model of decision-making highlights three main components: the planning process or what happened before the lesson, the interactive decisions or what occurred during the lesson, and the interpretative processes as the teacher engaged in retrospective examination after the lesson.

A preliminary conclusion in relation to teachers' mental lives, as stated by Freeman (2002), is that while accurate maps of teaching can be observed by studying it from the outside in, what is truly happening will not be grasped until the people who are doing it articulate what they understand about it. This promotes a perspective from inside out, teachers constructing knowledge about how to teach as a result of being mentally engaged with the teaching process. Johnson (2006) similarly emphasizes that:

Teacher educators should no longer ignore the fact that teachers' prior experiences, their interpretations of the activities they engage in, and the contexts within which they work are extremely influential in shaping how and why teachers do what they do Johnson, 2006, p. 236)

Accordingly, helping beginning teachers to interpret and give meaning to their own experiences might lead them to develop empirical and pedagogical insights which will

In Colombia, this reflective model has been widely cited (Cuesta et al., 2019; Viáfara, 2005; Chaves \& Guapacha, 2016) but often in terms of highlighting its benefits or advantages. 
simultaneously allow them "to theorize from practice and practice what they theorize" (Kumaravadivelu, 1994, p. 27).

This second approach considers then that learning to teach is shaped by teachers' previous learning experiences as students, as language learners, and as learners of language teaching. For instance, Lin (2005) emphasizes that "a teacher's experience as a student before she enters the teacher education program could have an impact on her experience as a teacher learner in such a program as well as on her actual teaching practice" (p. 11). In another study with four ESL student teachers, Gutiérrez (1996) identified the origins of these teachers' pre-training knowledge as connected to formal and informal language learning experiences, the way they were taught during their schooling years, their fellow students and other people they interacted with in different situations.

As admitted by Freeman and Johnson (1998), teachers' hidden pedagogy and past experiences as learners tend to create ways of thinking about teaching that often conflict with the images of teaching advocated in teacher education programs. Thus, these authors argue that teacher educators now have come to realize that prior knowledge is a powerful factor in teacher learning in its own right, one that clearly deserves attention and study so as to strengthen and improve, rather than simply preserve and replicate, educational practice. This is equally supported by Yates and Muchiski (2003) who claim that language teacher educators have experiences as language learners and language teachers and should therefore be aware of how coursework alone becomes insufficient for helping a teacher learner become a competent language teacher.

\section{The Social Context in Learning to Teach}

A third approach emphasizes how the role of social and cultural context contributes to shaping teacher learning and thinking. Learning to teach is not merely an individual and isolated task. It is a process embedded in the social, political, economic, and cultural circumstances of the contexts where teachers study, the contexts where they later receive initial preparation and induction to teaching, and the contexts where they eventually teach and integrate professionally with colleagues. As part of a socially-situated view of learning to teach, Johnson and Freeman (2001) propose a framework for the knowledge base of

220 language teacher education based on three interrelated domains which, according to the authors, describe the sociocultural environment where individuals learn to teach and carry out their work as teachers.

The first domain refers to teachers as learners of teaching contrary to their students or themselves as learners of language. The second domain seeks to integrate schools as the physical settings where teaching and learning occur and schooling as "the socio-cultural processes of participation in schools, processes that gain value and meaning for participants 
An Overview of Dominant Approaches for Teacher Learning in Second Language Teaching

through time" (Johnson \& Freeman, 2001, p. 59). The third domain centers on the activity of teaching and learning as experienced by teachers and learners in classrooms. This involves examining...

How teachers think (or theorize) about their work, how they transform content to make it accessible to ... learners, how they understand and function within the institutions in which they teach, how their learning relates to what and how students learn in their classrooms. (Johnson \& Freeman, 2001, p. 60)

In short, the authors emphasize that it is only by examining the sociocultural context that language teachers go through as learners of language teaching that the teacher education community can come to understand teacher learning in the North American context.

Freeman (2016) more recently incorporated many of the previous ideas in the concept of learning-in-place or situated learning theory which emphasizes elements such as learning by doing things in contexts, and knowing in situations (original italics). One of the greatest challenges of situated learning theory relates to the congruence between language as situated content and teacher education as situated preparation. Other central ideas for teacher education from the perspective of situated learning theory involve, according to Freeman (2016), language teachers as teacher educators, training new teachers through teaching actual language students, and learning collectively from and with one another - in situ.

This third approach for teacher learning also relies on a sociocultural perspective through which learning to teach becomes "a continual, mutually mediating process of appropriation and social action, where practitioners take on the cultural practices that are valued in the social situations of their development... and employ them in turn to shape that social situation" (Ellis, Edwards, \& Smagorinsky, 2010, p. 4). This social perspective allows the analysis of elements that are inherent to teacher learning such as the relevance of dialogue and collaboration in the construction of knowledge, the status of the teaching profession, the cultural norms of school and schooling, and the use of action research as a fundamental tool to generate theories of social change.

Going back to the idea of mediation in learning to teach, Johnson (2009a) points out how teacher learning is mediated by social practices and tools (e.g., scientific concepts, everyday concepts, human and social relations) and that these constitute a temporary "other" which "support the transformative process and enable each teacher to move from external social activity to internal control over their cognitive and emotional states" (p. 39). It follows that through these mediators, teachers were able to challenge their ways of thinking about teaching and develop new conceptions of teaching. Johnson (2009b) argues that second language teacher education programs are beginning to see language teaching as "a dialogic process of co-constructing knowledge that is situated in and emerges out of participation in particular sociocultural practices and contexts" (p. 21). In short, learning to teach, Johnson 
(2009b) adds, is not seen as "the straightforward appropriation of skills from the outside in, but [as] the progressive movement from externally, socially mediated activity to internal control by individual teachers" (p. 2).

As this approach involves a careful examination of the context, Freeman's (1996a) interpretivist view of teaching may have a role to play here as it suggests that action and thinking are now accompanied by the interpretation of the context. Put differently, this view of teaching is a more complex one in which teachers know the behaviors, are cognitively and affectively engaged with what goes on in class and know what to do in complex contexts, thus displaying interpretative knowledge of teaching. Johnson and Freeman (2001) reinforce this idea when they claim that "how teachers actually use their knowledge in classrooms has come to be seen as highly interpretive, socially negotiated, and continually restructured within the classrooms and schools where teachers work" (p. 56).

\section{Current Trends in Learning to Teach Second Languages}

We came to the conclusion that a current trend in learning to teach in second language teacher education across several international settings seeks to combine features of the second and third approaches previously described. In other words, elements such as teacher cognition, teachers' experiential knowledge and the social conditions of the teaching setting appear to play a more relevant role. Wright (2010) states that an emerging pedagogy in second language teacher education emphasizes aspects such as "student teachers' LEARNING to teach, ... becoming a THINKING teacher, ... REFLECTIVE ACTIVITY, ... student teacher INQUIRY, ... and ...LEARNING FROM EXPERIENCE” (uppercase in original) (p. 273). This reflects a particular trend to teacher learning in which teachers are expected to be cognitively, affectively, and socially engaged with respectful regard for the impact of their prior learning experiences. The following studies, compiled with a broad international readership in mind, help to illustrate this current trend as they lead us to understand how second language teachers learn to teach in different contexts around the world.

Barahona (2014a) examined the social origin of teachers' beliefs in the activity of learning to teach with a group of twenty-four EFL teachers in Chile. She found that teachers' beliefs are shaped and reshaped as teachers engaged in the activity of learning to teach English: from their past experiences as language learners, to teacher learners in a university teacher education program, and then to their school-based actual teaching experiences. These teachers' beliefs "emerged in the actions they engaged in learning to teach English and the interplay between theory, personal understandings and practical applications" (p. 120). The author highlights that these pre-service EFL teachers' beliefs kept changing as they engaged in professional teaching and that, consequently, they used their beliefs about learning and teaching to direct their actions. 
Kang and Cheng (2014) investigated the relationship between a novice EFL teacher's classroom practices and cognition development as she learned to teach in her everyday work in a middle school in Beijing, China. Results revealed a considerable amount of teacher 'change' while the factors that influenced such change included the teacher's professional learning experience, teaching experience, their reflection on practice, and the teaching context. This study contributes to validate the view that many second language teachers tend to practice what they have experienced as opposed to what they have studied in teacher preparation programs. The study also shows that the development of teacher cognition is the result of a continuous process of interaction between teachers' knowledge and belief systems and their classroom practices under the mediation of teacher reflection.

In examining the current practices of three pre-service English teachers in Hong Kong, Tsang (2004) found that about half of the interactive decisions in these teachers' lessons were guided by explicit maxims; the other half seemed to be connected to contextual factors such as limited class time, students' language level, and classroom management issues. A major implication here is that teachers' actions and decision making must not be understood with exclusive reference to what they think or know; an understanding of their teaching context and work setting is also necessary. Vieira (2006) focused on how the beliefs, assumptions, and knowledge that prospective EFL teachers in Brazil bring to their teacher education program interacted with the practical and theoretical content they were exposed to in such a program. The last phase of the project revealed that participants' teaching practice reflected new perspectives which were constructed during the teacher education program. This supports the importance of reflecting on theories and practices for teachers' knowledge construction. Vieira (2006) highlights that a teacher education program based on a social-constructivist view of teaching that accounts for the beliefs, assumptions and knowledge students bring to such a program, provides elements for the construction of a more coherent classroom practice.

Childs (2011) followed a novice ESL teacher in exploring his experiences in becoming a teacher in the United States. The study was conducted within a sociocultural perspective to analyze this teacher's struggle to conceptualize teaching. Findings show that this teacher's learning to teach process was mediated by several activity systems: his language learning beliefs (language learning as social practice), balancing his roles as a graduate student and a novice teacher, his support systems (coming from supervising professor, the professional development program, other ESL teachers, graduate courses), and his classroom teaching activity. Childs (2011) reports that although this teacher participated in these same activities in both semesters of professional teaching, the context of each activity changed from the first to the second semester. The study also confirms the view of teacher learning as a twisting path shaped and reshaped by different settings and communities of practice (Smagorinsky, Cook, \& Johnson, 2003) that individually and collectively comprise the first-year teaching experience. 
Farrell (2003) similarly reports on the role that support plays as a beginning EFL teacher experienced his first year of teaching in a school in Singapore. The author focused on the teacher's specific context, the school, and how he interpreted his own process of becoming a teacher during that first year. Findings relate to three major aspects: the reality of this teacher's first year characterized by an increase in his workload and in having to cope with lower proficiency students; the role of support from colleagues and administrators which led him to experience a culture of individualism with limited opportunities of sharing and communicating with colleagues; and a series of phases this teacher went through during the year where he moved from an initial shock regarding the reality of the classroom to paying more attention to the quality of his students' learning.

Studies by Johnson (2007) and Johnson and Golombek (2011a) serve to illustrate the use of narratives as representations of a socially-mediated view of human experience. Johnson (2007), for example, analyzed an ESL teacher's narrative with an emphasis on what it revealed about the internal activity of teacher learning, and the cultural artifacts this teacher relied on to mediate her learning. Findings showed that teacher-authored narratives allowed this teacher to "integrate theoretical and experiential knowledge as she articulated a rationale for reconceptualizing her instruction" (p. 185). The teacher in the study similarly relied on cultural artifacts to mediate her learning. These artifacts took various forms: interaction with a co-teacher with whom she was able to externalize her thoughts; theoretical constructs which she appropriated and reconfigured; the enactment of new instructional practices; and the narrative inquiry itself, in which, according to Johnson (2007), this teacher documented "the struggles she experienced as she regained self-regulation and resolved her sense of emotional dissonance" (p. 185) she had initially revealed.

Johnson and Golombek (2011a) later state that the use of narrative as a mediational tool involved three interrelated functions: narrative as externalization, narrative as verbalization, and narrative as systematic examination. Narrative as externalization leads teachers to disclose their current and tacit understandings and feelings so that these could be exposed to social influence and restructuring. Narrative as verbalization involves the use of concepts (every day and scientific) as tools for understanding or facilitating the internalization process. Johnson and Golombek (2011b) claim that "scientific concepts are presented to teachers in order to restructure and transform their everyday concepts so that they are no longer constrained" by 224 Lortie's (1975) apprenticeship of observation. Narrative as systematic examination seeks to engage teachers in systematic examinations of themselves, their teaching practices, and their social, historical, cultural, and political contexts that constituted their professional worlds in particular ways. Together these functions contribute to fostering teacher learning within what Johnson and Golombek (2011a) called the transformative power of narrative.

Other studies (Poehner, 2009; Kiely \& Davis, 2010) have also identified how learning to teach in second language education takes place through collaborative work and reflective 
practice. Poehner (2009) studied how a Vygotskian theoretical framework contributed to understanding teacher learning in the context of a critical friends' group in a small university town in the United States. He found that as a result of interacting with the critical friends' group, the participating teacher was able to build on her own history and the professional expertise provided by the group to reconceptualize the dilemma she had presented to the group and so was able to transform her instructional activities in ways that enhance student learning.

In working with more experienced English language teachers in a continuing professional development program in the United Kingdom, Kiely and Davis (2010) found that reflective practice was less successful, even though the analysis of Critical Learning Episodes of teachers' own lessons reaffirmed the value of collaborative work in learning to teach while reading research literature in the field of English language teaching to facilitate the analysis of episodes. A reflective approach to teacher learning that allows the inclusion of previous experiences and teachers' beliefs and personal theories of teaching can also be found elsewhere (Vélez-Rendón, 2002; Richards \& Farrell, 2011).

Teacher learning along with other related constructs (e.g., teacher identity, teaching methods, reflection), has also been of interest to local researchers in the Colombian context. For instance, the work of Fajardo (2014) reasserts the view that although learning to teach is individually constructed and experienced, it is socially negotiated, that is, it occurs as teachers negotiate ways of participation in a teacher community. The same author adds that learning to teach "is characterized by continuous interaction, communication, and social participation within the school community, local education authority, and broader contexts of professional connection" (p. 56). In contrast, Diaz (2013) examined the process of identity formation of a group of student teachers through a reflection cycle. He concluded that "identity is a social process that evolves in the settings where people learn and interact simultaneously" (p. 47), whereas reflection allows student teachers to think of new possibilities to act within the teaching context while shaping their self-images as teachers.

In conducting a study with thirty-two modern language graduates from a Colombian university, Mosquera (2021) reveals that "the most used methods and approaches that graduates prefer are the Communicative Language Approach and the Eclectic Method" (p. 112) and highlights the teaching and learning context, and resources as fundamental criteria for adopting such methods. This finding appears to reinforce the view that the circumstances of the contexts where teachers study and later teach, shape and restructure their teaching methods and approaches through a reflective-creative action and not merely an imposition of contextualities.

Castañeda-Trujillo and Aguirre-Hernández (2018) reported on a pedagogical experience with pre-service English teachers in the Colombian teacher education context. Interestingly, 
the authors mentioned the necessity, stressed by participants, of reflecting on their teaching, to think about all that happens in their classes including the impact they have on students' lives. Castañeda-Trujillo and Aguirre-Hernández (2018) also emphasize "the importance of having mentoring, not as a one-way process, but as a multiple-way process in which preservice teachers are able to feel they can express themselves and their peers and mentor are going to listen" (p. 164). This study contributes to the discussion on learning to teach second languages from a local - to us - perspective, and points at taking into consideration the reflections of those "directly involved in the [teaching] process" (p. 169), mainly as an opportunity to explore our habituation to traditional - and maybe incongruous - methodologies.

\section{Conclusions}

Teacher learning in second language teacher education across international settings has experienced various moves in its relatively short history. It has moved from a processproduct paradigm with an emphasis on teachers' behaviors and students' outcomes, to a consideration of teachers' cognitions and prior learning experiences, and more recently to be embedded in the social and institutional context of teaching. It is clear that the processproduct paradigm has become insufficient to fully understand teachers' hidden pedagogy and the complexity of classrooms, schools and communities where learning to teach occurs. In contrast, there seems to be a movement towards an ecological perspective with a focus on teachers' own experiences as insiders and a closer examination of the variables that influence the learning environment. Ecological studies hold the idea that classrooms are environmental settings and rely on the assumption that "one needs to take into account the affordances and constraints created by teachers, peers, and other human actors, not just the settings' physical characteristics" (Brophy, 2006, p. 27).

Despite the relevance of the various approaches and designs in second language teacher education worldwide, Freeman (2016) argues that designs such as learn-then-apply continue to be predominant in teacher preparation despite the fact that disciplinary knowledge seems to play a less central role in the knowledge base of language teaching in the last few decades. Nonetheless, other conceptual changes "have had little influence on the learn-thenapply framework ... [and] on how teaching knowledge is treated throughout a teacher's career" (p. 192). This review has led us, the authors, to believe that the learning to teach process in second language teacher education should be based on the interactions among social, cultural, and historical contexts. Additionally, we argue that the same process should rely on the interplay between teachers' hidden pedagogy and the individual and collective reconstruction of their experiential knowledge. As claimed by Barahona (2014b), "learning to teach is not a solo activity but a confluence of the pre-service teachers' personal histories (for example, no English, poor schools), the culture of the university (diverse and socially 
committed), and the nature of the pre-service teacher education program (critical, and change agents)" (p. 63). Thus, we can now more confidently reaffirm the view that language teachers do not learn to teach as a result of just mastering the language and pedagogical skills, or by exploring their own prior experiences, mental lives, or the social characteristics of their teaching context. Instead, it is the sum of these and many other aspects that eventually illuminates the developmental path of learning to teach for language teachers.

\section{Implications for Language Teacher Educators}

Language teacher educators in teacher preparation programs around the world should put themselves in a position to consider aspects of several approaches framed within the local needs and conditions of those involved in learning to teach. For example, several researchers (for example, Loughran, 2012; Borg, 2009; Johnson, 2006, 2009b) have claimed that teacher educators must work on acknowledging, helping make explicit, and challenging prospective teachers' prior cognitions and learning experiences as an important precondition within a transformational view of learning to teach.

Teacher educators in diverse second language teacher education programs should consider the benefits of collaborative work and communities of practice in teacher learning. This should lead to the establishment and maintenance of school-university partnerships, as well as other forms of collaborative inquiry (e.g., critical friends groups, team teaching, action research, online discussion groups, etc.) to help reduce the existing gap between the skills and knowledge typically gained in teacher education programs and the practical reality of the workplace. Teacher educators should also promote the development of adaptive expertise (Hammerness et al., 2005) so that teachers can adapt in appropriate ways and innovate within the constraints while they gain awareness of the larger social contexts within which they operate.

Finally, language teacher educators should help prospective teachers to understand that their views of teaching will develop over time. This, according to Childs (2011), can remove the pressure teachers might feel to "get it" immediately and also may remind teacher educators "to have realistic expectations of their students" growth and development" (p. 84).

\section{References}

Atay, D. (2004). Collaborative dialogue with student teachers as a follow-up to teacher in-service education and training. Language Teaching Research, 8(2), 143-162.

Barahona, M. A. (2014a). Pre-service teachers' beliefs in the activity of learning to teach English in the Chilean context. Cultural-Historical Psychology, 10(2), 116-122. 
Barahona, M. A. (2014b). Exploring the curriculum of second language teacher education in Chile: A case study. Perspectiva Educacional. Formación de Profesores, 53(2), 45-67.

Barnes, M., \& Smagorinsky, P. (2016). What English/language arts teacher candidates learn during coursework and practice: A study of three teacher education programs. Journal of Teacher Education, 67(4), 1-18. https://doi:10.1177/0022487116653661

Borg, M. (2004). The apprenticeship of observation. ELT Journal, 58(3), 274-276.

Borg, S. (2003). Teacher cognition in language teaching: A review of the research on what teachers think, know, believe and do. Language Teaching, 36(2), 81-109. https://doi:10.1017/ S0261444803001903

Borg, S. (2006). Teacher cognition and language education: Research and practice. Continuum.

Borg, S. (2009). Language teacher cognition. In A. Burns \& J. C. Richards (Eds.), The Cambridge guide to language teacher education (pp. 163-171). Cambridge University Press.

Brophy, J. (2006). History of research on classroom management. In C. Evertson \& C. Weinstein (Eds.), Handbook of classroom management: Research, practice, and contemporary issues (pp. 17-43). Routledge.

Buendía, X. P., \& Macías, D. F. (2019). The professional development of English language teachers in Colombia: a review of the literature. Colombian Applied Linguistics Journal, 21(1), pp. 98-111.

Castañeda-Trujillo, J. E., \& Aguirre-Hernández, A. J. (2018). Pre-service English teachers' voices about the teaching practicum. HOW, 25(1), 156-173. https://doi.org/10.19183/how.25.1.420

Chaves, O., \& Guapacha, M. E. (2016). An eclectic professional development proposal for English language teachers. Profile: Issues in Teachers' Professional Development, 18(1), 71-96. http:/ /dx.doi. org/10.15446/profile.v18n1.49946

Childs, S. (2011). Seeing L2 teacher learning: The power of context on conceptualizing teaching. In K. Johnson \& P. Golombek (Eds.), Research on second language teacher education (pp. 67-85). Routledge.

Cuesta Medina, L., Alvarez Ayure, C. P., Cadena Aguilar, A., Jiménez Bonilla, M. S., Maldonado Chacón, P. P., \& Morales Pulido, V. (2019). Beyond the endorsement of reflection in language teaching and learning. Colombian Applied Linguistics Journal, 21(1), 42-63. https://doi. org/10.14483/22487085.13307

Diaz, D. M. (2013). The way student-teachers construct their identity at school. HOW, 20(1), 3650 .

Doyle, W. (1977). Paradigms for research on teacher effectiveness. Review of Research in Education, 5(1977), 163-198.

Duarte, I. (1998). Research in second language teacher education, TESOL Quarterly, 32(3), 617622.

Ellis V., Edwards A., \& Smagorinsky P. (2010). Cultural-historical perspectives on teacher education and development: learning teaching. Routledge. 
An Overview of Dominant Approaches for Teacher Learning in Second Language Teaching

Fajardo, J. A. (2014). Learning to teach and professional identity: Images of personal and professional recognition. Profile: Issues in Teachers Professional Development, 16(2), 49-65.

Farrell, T. (2003). Learning to teach English language during the first year: Personal influences and challenges. Teaching and Teacher Education, 19, 95-111.

Feiman-Nemser, S. (2008). Teacher learning: How do teachers learn to teach? In M. CochranSmith, S. Feiman-Nemser, \& J. McIntyre (Eds.), Handbook of research on teacher education (pp. 697-705). Routledge.

Freeman, D. (1989). Teacher training, development and decision-making: A model of teaching and related strategies for language teacher education, TESOL Quarterly, 23(1), 27-45.

Freeman, D. (1996a). Redefining the relationship between research and what teachers know. In K. Bailey \& D. Nunan (Eds.). Voices from the language classroom (pp. 88-115). Cambridge University Press.

Freeman, D. (1996b). "The unstudied problem": Research on teacher learning in language teaching. In D. Freeman \& J. C. Richards (Eds.), Teacher learning in language teaching (pp. 351-371). Cambridge University Press.

Freeman, D. (2002). The hidden side of the work: Teacher knowledge and learning to teach. Language Teaching, 35, 1-13.

Freeman, D. (2016). Educating second language teachers. The same things done differently. Oxford University Press.

Freeman, D., \& Johnson, K. (1998). Reconceptualizing the knowledge-base of language teacher education, TESOL Quarterly, 32(3), 397-417.

Gutiérrez, G. (1996). Student foreign language teacher's knowledge growth. In D. Freeman \& J. C. Richards (Eds.), Teacher learning in language teaching (pp. 50-78). Cambridge University Press.

Hammerness, K., Darling-Hammond, L., \& Bransford, J. (2005). How teachers learn and develop. In L. Darling-Hammond \& J. Bransford (Eds.), Preparing teachers for a changing world (pp. 359389). Josey Bass.

Johnson, K. (2006). The sociocultural turn and its challenges for second language teacher education. TESOL Quarterly, 40(1), 235-257.

Johnson, K. (2007). Tracing teacher and student learning in teacher-authored narratives. Teacher Development, 11(2), 175-188.

Johnson, K. (2009a). Second language teacher education. A sociocultural perspective. Routledge.

Johnson, K. (2009b). Trends in second language teacher education. In A. Burns \& J. C. Richards (Eds.), The Cambridge guide to language teacher education (pp. 20-29). Cambridge University Press.

Johnson, K., \& Freeman, D. (2001). Teacher learning in second language teacher education: A socially-situated perspective. Rev. Brasileira de Linguistica Aplicada, 1(1), 53-69.

Johnson, K., \& Golombek, P. (2011a). The transformative power of narrative in second language teacher education. TESOL Quarterly, 45(3), 486-509.

Johnson, K., \& Golombek, P. (2011b). Research on second language teacher education. Routledge. 
Joyce, B., \& Showers, B. (2002). Student achievement though staff development ( $3^{\text {rd }}$ ed). Association for Supervision and Curriculum Development.

Kang, Y., \& Cheng, X. (2014). Teacher learning in the workplace: A study of the relationship between a novice EFL teacher's classroom practices and cognition development. Language Teaching Research, 18(2), 169-186.

Kiely, R., \& Davis, M. (2010). From transmission to transformation: Teacher learning in English for speakers of other languages. Language Teaching Research, 14(3), 277-295.

Kolb, D. A. (1984). Experiential learning: Experience as the source of learning and development. Prentice-Hall.

Kumaravadivelu, B. (1994). The post method condition: (E)merging strategies for second/foreign language teaching. TESOL Quarterly, 28(1), 27-49.

Lin, F. (2005). Knowledge base of English as a second language teachers. Dissertation proposal. Available: http://www.ut-ie.com/s/samples/fu-an_lin.pdf

Lortie, D. (1975). Schoolteacher: A sociological study. University of Chicago Press.

Loughran, J. (2012). Professional learning - creating conditions for developing knowledge of teaching. In M. Kooy \& K. Van Veen (Eds.), Teacher learning that matters (pp. 47-63). Taylor \& Francis.

Mosquera, E. (2021). English teaching methodologies of modern languages graduates from a university in Colombia. HOW, 28(1), 94-120 https://doi.org/10.19183/how.28.1.581

Poehner, P. (2009). Teacher learning through critical friends' groups: Recontextualizing professional development in a K-5 school. In K. Johnson \& P. Golombek (Eds.). Research on second language teacher education (pp. 189-203). Routledge.

Richards, J. C. (1987). The dilemma of teacher education in TESOL. TESOL Quarterly, 21(2), 209-226.

Richards, J. C. (1990). The dilemma of teacher education in second language teaching. In J. C. Richards \& D. Nunan (Eds.). Second language teacher education (pp. 3-15). Cambridge University Press.

Richards, J. C. (1998). Beyond training. Cambridge University Press.

Richards, J. C., \& Farrell, T. (2011). Practice teaching - A reflective approach. Cambridge University Press.

Smagorinsky, P., Cook, L. S., \& Johnson, T. S. (2003). The twisting path of concept development in learning to teach. Teachers College Record, 105(8), 1399-1436.

Tarone, E., \& Allwright, D. (2005). Second language teacher learning and student second language learning: Shaping the knowledge base. In D. Tedick (Ed.), Second language teacher education. International perspectives (pp. 5-23). Lawrence Erlbaum Associates.

Tsang, W. K. (2004). Teachers' personal practical knowledge and interactive decisions. Language Teaching Research, 8, 163-198. 
An Overview of Dominant Approaches for Teacher Learning in Second Language Teaching

Vélez-Rendón, G. (2002). Second language teacher education: A review of the literature. Foreign Language Annals, 35(4), 457-467.

Viáfara, J. J. (2005). The design of reflective tasks for the preparation of student teachers. Colombian Applied Linguistics Journal, (7), 53-74. https://doi.org/10.14483/22487085.165

Vieira, M. H. (2006). The construction of theoretical and practical knowledge in initial teacher education. Profile: Issues in Teachers' Professional Development, 7, 87-99.

Wallace, M. (1991). Training foreign language teachers: A reflective approach. Cambridge University Press.

Woods, D. (1996). Teacher cognition and language teaching. Cambridge University Press.

Wright, T. (2010). Second language teacher education: Review of recent research on practice. Language Teaching, 43(3), 259-296.

Yates, R., \& Muchiski, D. (2003). On reconceptualizing teacher education. TESOL Quarterly, 37(1), 135-147. 